\title{
Boko Haram insurgency, counter-insurgency and violation of human right, a critique. Omoteinse Gaius $\mathbf{O}$. University of Ibadan Peace and Conflict studies
}

\section{Introduction}

The most recent extremist group in Nigeria, Boko Haram, continues to grow, committing various extremist acts, such as sporadic suicide bombings and killing of innocent citizens and foreigners within the country. The fabric of Nigeria's unity appears to be ripped by violent extremism and homegrown insurgency . Violations of human right has been on the increase, perpetuated by the insurgents and the security personnels especially in the north east.

To begin with, it is important to define insurgency, counter insurgency and the violations of human right.

Insurgency according to wikipedia is a rebellion against a constituted authority when those taking part in the rebellion are not recognized as belligerents. According to Gordon H. McCormick, an insurgency is a struggle for control over a contested political space, between a state (or group of states or occupying powers), and one or more popularly based, non-state challengers. 
Counter-insurgency on the other hand consist of those measures used by the government to tackle insurgency.it is a comprehensive civilian and military efforts taken to simultaneously defeat and contain insurgency and address its root causes.

Violation of human right refers to those actions that tend to dehumanize human beings; it consists of acts that infringe on the fundamental human right of people irespective of age, gender, religion, ethnic group or race. Human rights are the fundamental features of any true democratic setting because the essence of democracy itself is based on the idea of human rights. Human rights are mostly viewed as the inalienable rights of people (Enebe, 2008).

\section{HISTORY OF BOKO HARAM}

The northern Nigeria of today comprises nineteen states, and to a very large extent,Abuja, the Federal Capital Territory (FCT). Despite the heterogeneous ethnic composition of the North, the Hausa-Fulani ethnic group still predominates, with over $70 \%$ of its people belonging to the Hausa-Fulani ethnic stock.The most important rallying point for unity among the Hausa states was Islam. The country, survived a brutal civil war in the late 1960s, in which more than 1 million people died. The country has witnessed repeated rounds of violence since then, often between Muslims and Christians, often fueled by politics. Boko Haram are Islamic jihadist and takfri militant sect based largely in the northeastern part of Nigeria, north of Cameroon and Niger (Shehu, 2011; Moses, 2012; Agbambu, Bwala, Ibrahim \& Usigbe, 2013; Burstin, 2013). Founded by Muhammed yusuf in 2002, the organization seeks to establish a - pure Islamic state ruled by sharia law, putting a stop to what it deems - Westernisation (Cook, 2011; Bartolotta, 2011; 
Ifowodo, 2013). The group has adopted its official name to be "the Congregation of the People of Tradition for Proselytism and Jihad, which is the English translation from Arabic Jamā'at ahl as-sunnah lid-da'wa wa-l-jihād (Wikipedia, 2014). In the town of Maiduguri, where the group was formed, the residents dubbed it Boko Haram. The term "Boko Haram" comes from the Hausa word boko figuratively meaning "western education" (literally "alphabet", from English "book") and the Arabic word haram figuratively meaning "sin" (literally, "forbidden"). The name, loosely translated from Hausa, means "western education is forbidden" and so sinful ((Wikipedia, 2014; Ogbonnaya, 2011). The group earned this name by its strong opposition to anything Western, which it sees as corrupting Muslims. However, this interpretation of the name is disputed, and locals who speak the Hausa language are unsure what it means (Wikipedia, 2014). Ideologically, Boko Haram was founded as an indigenous group, turning itself into a Jihadist group in 2009. It proposes that interaction with the Western world is forbidden, and also supports opposition to the Muslim establishment and the government of Nigeria. Because of this hard lined position, the members of the group do not interact with the local Muslim population and have carried out assassinations in the past of anyone who criticises it, including Muslim clerics.

Boko Haram therefore, emanated from an orthodox teaching slightly resembling that of the Taliban in Afghanistan and Pakistan. Late Sheikh Muhammed Yusuf (Jan 1979-July 2009) was the leader of the group. Their school of thought considers anything western as an aberration or completely unislamic. The group viewed the western influence on Islamic society as the basis of the religion's weakness. Hence their declaration that western education and indeed all western institution is infidel and as such must be avoided by Muslims.Many young people dropped out of school, including university student to join them, workers including highly placed administrators and tertiary institution lecturers also joined 
them,many youths separated from their families, while many people abandoned their jobs for the group.

Also, most people sold their belongings to contribute to the coffers of fighting the cause of Allah to save Islam from the clutches of western influences and domination (Ogundipe 2012). At the initial stage of their growth, the sect was entrenched in Borno, Yobe, Katsina, Kaduna, Bauchi, Gombe and Kano States, but now have covered virtually all northern states and are advancing their frontiers to other parts of the country (Nossiter, 2012; Abrak, 2013; Gillian, 2013). Mohammed Yusuf the leader, had severally described his groups as non-militants, but simply a group of youths who are bent on upholding the words of Allah. He warned that they will rather die than to succumb to the present corrupt system in the country.The group vowed to continue to fight the authorities and their accomplices until they succeed or die in the process.

Yusuf argued that Western education, or - boko had brought nothing but poverty and suffering to the region and was therefore forbidden, or - haram, in Islam. He began peacefully by mostly preaching, and he quickly gained a following among disaffected young men in the northeast. But his anti-establishment rhetoric and hints that Boko Haram was building an arsenal of weapons also caught the attention of the authorities. In truth, the authorities could hardly claim ignorance of the activities of Mohammed Yusuf and his men.

As a matter of fact, he was arrested on several occasions by the police in Maiduguri but before the police could roll out the drums and start celebrating his capture, Yusuf would have resurface in his vast compound in Maiduguri. According to (Shehu, 2011) there was a time when he returned from Abuja barely five days after his arrest and people from Kaduna, Bauchi and Kano came to welcome him. There was a long motorcade from the airport as thousands of his members trooped out to lead him to his house. 
The extremist group has said it is fighting to establish an Islamic state in northern Nigeria and has carried out waves of attacks across the region. The group is known today for attacking Christians, government targets, bombing churches, attacking schools, police stations, army barracks, kidnapping western tourists and also assasinated members of Islamic establishments that criticized them (Njadvara \& Gambrell, 2011; brock, 2011; Olubode, 2011; Lobel, 2012; Campbell, 2013).

Some of the violence has occurred along the northern borders with Cameroon, Chad and Niger amid fears that Boko Haram fighters could spill into neighbouring states. In 2009, the police clamped down on the sect members who were ignoring a law requiring motorcyclists to wear crashhelmets. That sparked a furious backlash. Police stations and government offices in Borno were burned to the ground, and hundreds of criminals released in a prison break, as the violence spread across northern Nigeria.The government and army reacted with force; Yusuf was captured and shot dead in police custody. Five days of fighting left some 800 people dead. The battle between security forces and followers of the Boko Haram sect came to an end with the killing of the leader of the group few hours after he was captured in Maiduguri.

The police claimed that Mallam Mohamed Yusuf whose followers battled troops and policemen for five days in many state, was reportedly killed in a shoot out with security men. A journalist said the body outside the state police headquarters had several gunshot wounds. It was learnt that before he was killed, Yusuf requested that people should pray for him to have the mercy of God. Violence linked to the Boko haram insurgency has resulted in an estimated 13, 000 deaths between 2001 and 2015 (Sani-Muh`d, 2010; Ibrahim, 2011; Doyle, 2012; Lasnier, 2012; Mark, 2012; Newsday, 2013; Campbell, 2013; Pernice, 2013; Gullian, 2013). Expectedly, being a die hard sect after the killing of mohammed Yusuf, the group carried out its first attack in Borno in January 2011. The attack resulted in the killing of four 
people. Since then, the violence has only escalated in terms of frequency, intensity and sophistication, as well as casualities. In January 2012, Abubakar Shekau, a former deputy to Yusuf, appeared on YouTube announcing his assumption of control of the jihadist Islamist extremist group Boko haram after the death of Mohammed Yusuf in 2009.

The Boko Haram men were largely known to have lived at Jadaman Mada near the Maiduguri airport where they have theirJummat mosque (Adefolarin, 2012). They neither buy commercial food, nor eat from dishes prepared by non members, due to its sources (Haram). In fact, they do not eat much, some of them are said to live on fruits and dairies only. They normally dress in similar costumes as the Taliban of Afghanistan or Pakistan, with longsleeve robe, shortened trousers, a turban, long beard, a small coat cover the longsleeves robe, covering the abdomen (like a bullet proof jacket) and a chewingstick.It is on record that member of this sect disowned their parents, buried member‘s certificates including masters Degree Certificates. Their main enemies were the state, the ruling classes and Nigeria's educated elite. According to Human right Watch, during the period between 2009 and beginning of 2012, Boko haram was responsible for over 900 deaths (Nossiter, 2012).

According to Tukur (2013) the Peoples Democratic Party (PDP) Chairman , - Today,there is fear everywhere, Churches are being burnt, Mosques are being attacked, United Nations building bombed, motor parks are being bombed. People cannot go to motor parks again to travel for the fear of being attacked. Security installations, such as police stations, prisons are being burnt down and inmates released at will. Nobody knows the next target of attack.Tukur, was expressing sadness over the security situation in the country, cited the recent attack on the prisons at Ganye, his country home in Adamawa State where over 100 inmates were set free while 25 were killed after which the prison was set ablaze, said —"This nation must come together to fight the common evil. There is fear 
everywhere. In my village, Ganye in Adamawa, they invaded the place, burnt down the police station, attacked the policemen on duty, raided the bank,burnt privately-owned houses, moved down to the prisons, set the inmates free and burnt down the building. Where are we heading to? Nobody can even explain what is happening now”.

\section{BOKO HARAM INSURGENCY, COUNTER INSURGENCY AND INCIDENCES OF VIOLATION OF HUMAN RIGHT}

Insurgent groups, particularly Boko Haram, threaten the very existence of Nigerian unity and have abbeted in creating the deadly cycle of fear, thereby exposing the Federal government's failure to exercise control. Despite the Nigerian government's declaration of a state of emergency in the three most affected northern states, namely Adamawa, Borno, and Yobe, violence has continued with no sign of abating there. With the 6weeks war waged against the sect by the government after the postponement of the general election on alleged insecurity, the soldiers are recording success against the insurgents and several villages have been liberated.

In recent times the Nigerian government has deployed over 8,000 soldiers to combat insurgents in these affected states, but the absence of a specific Military Code of Justice to clearly identify intended targets and protect civilians has further increased the number of casualties in Northern Nigeria. For example, the Nigerian Army conducted a single deadly military intervention that caused wanton destruction of civilian lives and property in Baga, Borno State, in northeasternNigeria on Sunday, April 21, 2013. The soldiers were searching for suspects believed to be members of Boko Haram and killed over 200 civilians in one day (Akande, 2013). This has been seen as a violation of human rights in many quarters. 
Casualties and human rights abuses associated with Boko Haram attacks and the government's response escalated. On April 24 2013, President Jonathan inaugurated a Committee on Dialogue and Peaceful Resolution of Security Challenges in the North. Self-appointed Boko Haram spokespersons rejected dialogue or amnesty. On May 14 2013, President Jonathan declared a six-month state of emergency in Borno, Yobe, and Adamawa states, which was extended for another six months on November 20.

The most serious human rights abuses during the year were those committed by Boko Haram, which conducted killings, bombings, abduction and rape of women, and other attacks throughout the country, resulting in numerous deaths, injuries, and widespread destruction of property; those committed by security services, which perpetrated extrajudicial killings, torture, rape, beatings, arbitrary detention, mistreatment of detainees, and destruction of property; and widespread societal violence, including ethnic, regional, and religious violence.

Other serious human rights problems included vigilante killings; prolonged pretrial detention; denial of fair public trial; infringements on citizens' privacy rights; restrictions on the freedoms of speech, press, assembly, religion, and movement; official corruption; violence against women; child abuse; sexual exploitation of children; trafficking in persons; discrimination based on sexual orientation, gender identity, ethnicity, regional origin, religion, and disability; forced and bonded labor; and child labor.

Throughout much of the country, Boko Haram perpetrated numerous killings and attacks, often directly targeting civilians. Boko Haram recruited child soldiers, claimed responsibility for coordinated assaults on social and transportation hubs in Kano; an attack on the town of Baga; multiple attacks on schools and mosques; an attack on the town of Benesheik; and the killing of government, religious, and 
traditional figures. On February 17, the terrorist group Ansaru, believed to be a Boko Haram faction, kidnapped seven foreigners in Bauchi State.

In 2014, with government and military support, a youth vigilante group known as the Civilian Joint Task Force (C-JTF) emerged in the Northeast, centered around Maiduguri. According to nongovernmental organization (NGO) and press reports, C-JTF members included children and committed extrajudicial killings. Violations of human rights were more evidenced in the following areas:

\section{a. Arbitrary or Unlawful Deprivation of Life}

Boko haram and the government and its agents committed numerous arbitrary or unlawful killings. The National Human Rights Commission (NHRC) and the Committee against Torture held mandates to examine security force killings and refer alleged perpetrators for prosecution but did not do so. Joint task forces (JTFs), composed of elements of the military, police, and other security services, conducted raids on militant groups and criminal suspects in the states of Adamawa, Bauchi, Borno, Gombe, Kano, Kaduna, Kogi, Plateau, Sokoto, Taraba, Katsina, Jigawa, and Yobe. These raids resulted in numerous deaths of and injuries to alleged criminals, militants, and civilians. Local NGOs, international human rights groups, and political and traditional leaders in the affected states accused the security services of indiscriminate and extrajudicial killings.

The national police, army, and other security forces committed extrajudicial killings and used lethal and excessive force to apprehend criminals and suspects as well as to disperse protesters. Authorities generally did not hold police accountable for the use of excessive or deadly force or for the deaths of persons in custody. The reports of state or federal panels of inquiry investigating suspicious deaths remained unpublished.

After a lull in activity following the declaration in May of a state of emergency, Boko Haram in August increased its attacks on police and security forces and 
civilian targets, including banks, bars, restaurants, religious sites, schools, and government buildings in the North. Shootings and bombings in Maiduguri, Borno State, and the surrounding countryside occurred on a weekly--and sometimes daily--basis, resulting in hundreds of deaths.

\section{b. Prison and Detention Center Conditions}

Prison and detention center conditions remained harsh and life threatening. Prisoners, a majority of whom had not been tried, were subject to extrajudicial execution, torture, gross overcrowding, food and water shortages, inadequate medical treatment, deliberate and incidental exposure to heat and sun, and infrastructure deficiencies that led to wholly inadequate sanitary conditions and could result in death. Reports indicated guards and prison officials extorted inmates or levied fees on them to pay for food, prison maintenance, and prisoner release. In some cases female inmates faced the threat of rape. Female prisoners pregnant at the time of incarceration gave birth to and raised their babies in prison. Domestic and international human rights groups reported the existence of unofficial military prisons, including the Giwa military barracks in Maiduguri, Borno State, and Sector Alpha (aka Guantanamo) and the Presidential Lodge (aka the Guardroom) facilities in Damaturu, Yobe State, among others. Human Rights Watch (HRW) and Amnesty International (AI) cataloged cases of illegal detention, inhumane and degrading treatment, beatings, torture, and extrajudicial killings in these prisons. Boko Haram suspects are held in facilities throughout the country, including reportedly in inhumane conditions at the Special Anti-Robbery Squad detention center, also known as the "abattoir," in Abuja. Detention of suspected militants did not always fall under the formal prison system structure. As of 
December 15, the country's prisons held 56,620 persons. Of these, 2 percent were women, and 1 percent were juveniles (human right watch 2014).0

\section{c. Arbitrary Arrest or Detention}

Although the constitution and law prohibit arbitrary arrest and detention, police and security forces continued to employ these practices. The JTF-RO arbitrarily arrested hundreds of persons during sweeps for boko haram insurgents.

\section{d. Arbitrary Interference with Privacy, Family, Home, or Correspondence}

The law prohibits such actions, but authorities infringed on these rights during the year, and police entered homes without warrants. Human rights groups and the media reported security forces raided homes without warrants while searching for suspected Boko Haram militants. In some instances this occurred immediately following a bombing or attack by suspected militants. In others the security forces conducted searches and seizures during planned sweeps through neighborhoods in which they suspected Boko Haram militants resided. During the year, although the government did not punish family members for alleged offenses committed by individuals, reports indicated security forces arrested and detained the family members of suspected Boko Haram militants. On May 31 2014, the military released 23 women and 38 juveniles detained on suspicion of having links to Boko Haram (human right watch 2014).

\section{e. Use of Excessive Force and Other Abuses in Internal Conflicts}

Security forces under the command of JTF-RO, the army's Seventh Division, the national police, the SSS, and other commands committed numerous killings.

The government claimed JTF-RO members faced disciplinary charges for human rights violations, but none was verified. According to eyewitnesses, press reports, 
and civil society reports, JTF-RO personnel allegedly committed numerous killings in Bauchi, Borno, and Yobe states, often after attacks by Boko Haram.

According to press and NGO reports, JTF-RO illegally detained and killed suspected members of Boko Haram in the Giwa barracks military facility in Maiduguri, Borno, and Sector Alpha and the Presidential Lodge facilities in Damaturu, Yobe. Former detainees alleged that torture and mistreatment by security forces led to the death of detainees in some cases. Authorities publicly denied the claims, describing them as inaccurate or unbalanced.

On April 16 2014, witnesses in the town of Baga, Borno State, claimed Boko Haram shot and killed a soldier with the Multinational Joint Task Force, composed of soldiers from Chad, Niger, and Nigeria. In response Nigerian army members of the task force shot indiscriminately at individuals and animals and destroyed homes and property. The chief of defense staff and the police claimed that approximately 36 persons were killed, but Senator Maina Maaji Lawan, who represents Baga in the National Assembly, claimed based on his own field visit to Baga that up to 228 persons may have been killed. In addition reports varied on the extent of property damaged in the incident. Senator Lawan estimated the soldiers destroyed up to 4,000 homes, mostly by fire.

On October 4, in its report Keep away from Schools or We'll Kill You: Right to Education under Attack in Nigeria, AI alleged that attacks during the year by Boko Haram and other groups in the North resulted in the deaths of 70 teachers and scores of students. Many others were injured. Thousands of students were forced out of school in communities across northern Nigeria, and many teachers fled for their safety. AI observed that during the year attacks became more targeted and brutal than in previous years, when schools were attacked mostly while they were empty. 


\section{f. Abductions:}

An increasing number of kidnappings had links with terrorism. For example, on February 17, members of Ansaru, a Boko Haram terrorist offshoot, killed a guard and kidnapped seven foreigners working for the construction firm Setraco International Holding Group from their compound in Jama're, Bauchi State. The victims were nationals of the United Kingdom, Italy, Greece, Syria, and Lebanon. In December 2012 Ansaru announced it abducted a French engineer who worked for energy firm Vergnet in protest against the proposed French military action in Mali against Islamist groups and the French ban on the full-face veil known as the niqab. On November 18, newspapers reported that the French hostage had escaped from his captors and returned to France.

\section{g. Child Soldiers}

During the year youths under the age of 18 participated in Boko Haram attacks. Reports suggested boys as young as 11 were paid to fight for Boko Haram, plant bombs, and serve as spies and suicide bombers. HRW reported direct participation in C-JTF activities of persons under 18. Witnesses described seeing children ages 15 to 17 working with C-JTF at checkpoints within several towns in Borno State. C-JTF members admitted to having used numerous children in operations, specifically to collect information.

\section{h. Other Conflict-related Abuses}

Domestic and international press and NGOs reported attacks on hospitals by government security forces. In May, according to press and social media reports, members of JTF-RO attacked Maiduguri Teaching Hospital and beat hospital staff and patients. C-JTF supplied the JTF-RO with information about suspected Boko 
Haram militants, apprehended suspected Boko Haram militants, and reportedly manned some checkpoints. During the year Boko Haram threatened to kill journalists and attack media outlets that failed to report what Boko Haram believed to be authentic stories about the group. For example, Ahmad Salkida, a reporter for online newspaper Premium Times, fled the country and went into hiding in April after turning down several requests from Boko Haram to publish exclusive Boko Haram interviews and materials. Salkida reported he had also been threatened by members of JTF-RO because his reporting on Boko Haram appeared to reveal his closeness to the group.

\section{i. Freedom of Assembly}

Although the constitution and law provide for freedom of assembly, the government occasionally banned gatherings when it concluded their political, ethnic, or religious nature might lead to unrest. In areas that experienced societal violence, police and security forces permitted public meetings and demonstrations on a case-by-case basis. Security forces used excessive force to disperse demonstrators during the year, resulting in numerous deaths and injuries (also see section 1.a.). Open-air religious services held away from places of worship remained prohibited in many states, due to fears they might heighten interreligious tensions. Police used gunfire to control or disperse political rallies.

On February 8, members of JTF-RO dispelled a group of approximately 100 women who were protesting the disappearances and prolonged detention of male members of their families in Maiduguri. JTF-RO members fired rifles into the air to disperse the crowd.

\section{j. Women}


Boko Haram abducted women and forced them to marry militants throughout the year. The over 200 girls kidnapped from Chibok are still missing. There have cases of rape by the insurgents. Women who were fortunate to excape from the boko haram nest recountered that they were raped on daily basis. Hoodlums have also used opportunities of the unrest to rape women across the Northeastern part of the country.

\section{EFFECTS OF HUMAN RIGHTS ABUSE IN NIGERIA}

Human rights abuse in Nigeria often leads to poverty which is so prevalent due to massive abuse of public fund. This is as a result of high rate of unemployment which has resulted in youth ${ }^{\text {ee }}$ involvement in crimes such as armed robbery, internet scams and kidnapping for survival. Secondly, human right abuse has obvious hindrance to national development. Thirdly, it also breeds high insecurity rate as a state of anarchy had given room to lack of protection of lives and properties as witnessed in the northern part of the country. Equally, the poor health care facilities and diseases are as a result of government non-challant attitude to the well-being of the citizens. Human right abuse has created unlawful detention and lawlessness with gross violation of the rule of law. Furthermore, human right abuse makes people unpatriotic as most Nigerians are not proud of calling Nigeria their fatherland. This is why many citizens of Nigeria seek ways of leaving the country in search of safety and prosperity abroad.

\section{Recomendation}

From the foregoing, it is evident that human rights abuse is a menace to any society because of its consequences. To overcome these challenges, the following recommendations are made: 
The Nigerian government should take more proactive campaign against corruption and strengthen the country ${ }^{\text {ee }}$ s anti - corruption institutions. This is because corruption serves to promote criminal and extremist activity by creating barriers to legitimate socio - political and economic endeavours. By attacking corruption, Nigeria will send a clear signal that the country is indeed committed to good governance, to the security of its citizens and to its rightful place as a significant actor on the global stage (McCulley, 2013).

The government has to amend some clauses in the Nigerian constitution like section 215 (5), 260(1), 275 (1) among others (Ezeanya, 2010). For instance, it is unjust for any government that claims to be secular to put loopholes in her constitution that guarantees state to adopt any religious law (like the enforcement of Sharia law on non- Muslims in the North). Also, if our leaders are genuinely sincere, then there is no reason why a President and Governor could not be questioned on abuse of office in the court of law. Hence, it is recommended that the immunity clauses in our constitution should be removed.

Moreover, freedom of the press and freedom of expression are also fundamental human rights, key to functioning democracies. A vibrant free press is critical to illuminating public discussion on issues arising from Nigeria ${ }^{e e}$ s democracy, including security and corruption. The silencing of journalists, political critics, and others, whether via arrest and detention, threats or other forms of intimidation should be outlawed in Nigeria. Respect for the rule of law is paramount and must start with the government itself. To this end, government should follow the rule of law. It has to ensure that corruption in the judiciary is stopped and checked by another agency. This will make it easier for the citizens to trust the judiciary and seek redress in court whenever their rights are abused (Kaluge, 2013; McCulley, 2013). 
With the restoration of democratic governance in all the countries in West African sub-region, there should be more conscious efforts by Nigerian government to ensure respect for, protection and fulfillment of human rights. This is why the National Human Rights Commission need to be repositioned to effectively discharge its mandate (Nnochiri, 2013). Along the same vein, government should provide Human Right Education to the citizens through media campaigns, lectures, and simulation exercises among others. This will help to educate the citizens on their rights and on how to seek redress when their rights are violated.

However, the Nigerian law enforcement agencies most importantly the Nigerian police needs re-orientation because they need to understand their duties as they have to learn that respecting the rights of the citizens are part of their duties. The military on the other hand should be taught to use less force when called upon to restore law and order. To this end, the government should allow the military to concentrate on defending the state against external aggression than quelling internal unrest. Rather, the police should be beefed-up and well-equipped so that they can combat most internal crimes effectively.

Above all, the citizens should not only help the government to protect their rights but they should also live responsibly to protect the rights of others at all levels of human relationship ranging from the family to the global arena. Hence, citizens should be more patriotic, have respect for the law, assist the law enforcement agencies and co-operate with international organizations on human rights issues. The prisons should also be upgraded and equiped to make life meaningful to the prisoners, poor prison facilities only make prisoners worse than they were before they went to prison and hence produce more bad criminals into the society rather than being a correctional facility. 


\section{References}

Abrak, I. (2013). —Boko haram rebels say Nigerian military offensive is failing. Reuters. Retrieved 2013-07 06.

Adefolarin, O. (2012). A Critical Examination Of The Boko Haram Insurgence Attacks In Nigeria and Possible Solutions, http://www.academia.edu/3331715/ Analysis.Unpublished B.Sc. thesis, Department of Psychology,University of Lagos.

Agbambu, C., Bwala, J., Ibrahim, H., and Usigbe L. (2013). —Bama attackers wereNigerians, Cameroonians\|. Nigerian Tribune. Retrieved 2013-05-09.

Burstin, A. (2013). - Boko haram and the risk of terrorism in northern Cameroon.ESISC ।Research Associate. Retrieved 2013-05-09.

Bartolotta, C. (2011). - Terrorism in Nigeria: The rise of Boko haram\| the world Policy Institute. Retrieved 22-01-2012.Greenwich, CT: JAI Press.

Brock, J. (2011). —Nigerian Islamist sect claims bomb attack: paperll. Reuters. Retrieved 2011-06-17

Campbell, J. (2013). —Should U.S. Fear Boko haram. CNN. Retrived 02-10-2013.

Campbell, J. (2013). Nigeria: Dancing on the brink. Rowman \& Littlefield Publishers: UK

Cook, D. (2011). - The rise of Boko Haram in Nigeriall. United State Military 
academy.

Country Reports on Human Rights Practices for 2013 United States, Department of State. Bureau of Democracy, Human Rights and Labor

Doyle, M. (2012). —African Islamist militants co-ordinate effortsll. BBC.

Retrieved 26-06-2012

Gillian, P. (2013). - In Boko haram country, Nigeria's new crackdown brings mixed feelings. CSMonitor.com. Retrieved 2013-07-06.

Enebe, G.C., 2008. The concept of human right: Origin, meaning and place in the new world. In O. Anichebe (Ed.). Logic, philosophy and human existence. 8th Edn., Nsukka: Afro-Orbis Publications.

Ezeanya, P.O.C., 2010. Tribes and tongues in Nigeria. Enugu: Professor"es Press. Ifowodo, O. (2013). —Nigeria: Boko haram's two-state solution to Nigeria.allafrica.com

Kaluge, D., 2013. Human right abuse. Available from http://davidkaluge.hubpages.com/hub/human-right-abuse [Accessed 4th November 2013].

Lobel, M. (2012). —Deadly attack on Nigeria‘s Bayero Universityll. BBC. Retrieved 5-5-2012

Mark, M. (2012). —Scores dead in Northern Nigerian as islamist militant terrorise the country. The Obsever. Retrieved 22-01-2012

McCulley, T.P., 2013. Nigeria ${ }^{\text {ee }}$ commitment to human rights. The Punch April 25. Available from www.punching.com. [Accessed 4th November].

Moses, C. (2012). —Boko haram killed Cameroonian mayorll. Pilot Africa. Retrieved 2013-05-11. 
Nnochiri, I., 2013. Human rights abuses in Nigeria worrisome - FG. Vanguard $\begin{array}{llll}\text { News } & \text { November } & 2 . & \text { Available }\end{array}$ http://www.vanguardngr.com/2013/04/human-rights-abuses-in-nigeriaworrisome-fg.html [Accessed 15th November].

Nossiter, A. (2012). —In Nigeria, a deadly group‘s rage has local rootsll. The New York Times.Retrieved 2012=02-27.

Ogundipe, T. (2012). -Tracking the sect's cash flowll. www.thenationonlineng.net.

Retrieved 20-03-2012.

Olugode, M. (2011). —Nigeria: we are responsible for Borno killings, says Boko haram.AllAfrica.com. Retrieved 31january 2012.

Pernice, M. (2013). —Nigeria's war on terrorism: Combatting Boko haram\|. World OutlineGroup.

Sani-Muhd, S. (2010). —Attack on Bauchi Prison-Boko haram frees 721 innmates. Allafrica.com. Retrieved 31-05-2011.

Shehu, S. (2011) . - Boko Haram: History, ideas and Revolt\| in The GurdianNewspaper,July 19, P88.

Tukur, B. (2013). BokoHaram was preparing to declare state of their own. The Guradian Newspaper, May15, P2.

Wikipedia, the free encyclopedia. Boko haram. Retrived, 02-25-2015.

Wikipedia, the free encyclopedia.Insurgency. retrieved 02-28-2015 


$$
\text { pe }
$$

